\title{
CORRIGENDUM
}

\section{Dynamic Changes in Proteins during Apple (Malus $x$ domestica) Fruit Ripening and Storage}

\author{
Yun Shi, Li Jiang, Li Zhang, Ruoyi Kang and Zhifang Yu
}

Horticulture Research (2014) 1, 14; doi:10.1038/hortres.2014.14;

published online 12 March 2014

Correction to: Horticulture Research (2014) 1, 6; doi:10.1038/hortres. 2014.6; published online 22 January 2014

Since the publication of this article, the authors have noticed an error in the reference 20, the name of the journal, the year and the pages of the reference should be "J Proteomics 2013; 78: 39-57."
These errors have now been rectified and the correct article appears in this issue. The html and online pdf versions have also been rectified and now carry the correct paper.

The authors apologize for any inconvenience it may have caused. 